\title{
Text Message
}

National Cancer Institute

\section{Source}

National Cancer Institute. Text Message. NCI Thesaurus. Code C157352.

A short electronic communication, usually sent and received by a mobile phone. 